\title{
Recent Advances in Bioinformatics Reveal the Molecular Heterogeneity of Hepatocellular Carcinoma
}

Prof. M. Kudo

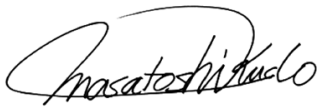

Editor Liver Cancer

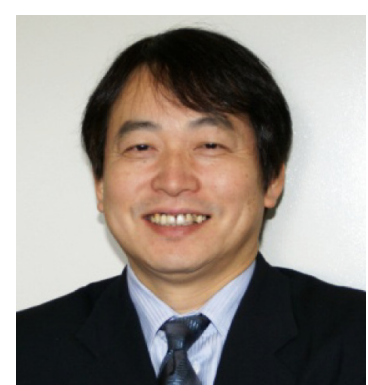

Bioinformatics is an academic field that manages information about materials and substances essential for the biological activities of genes, proteins, and RNA. Bioinformatics enables vast amounts of biological data to be made available for statistical analysis to improve our understanding, diagnosis, and treatment of diseases. In recent years, genome-wide association studies (GWAS) and next-generation DNA sequencing technology have made it possible to generate large amounts of data very quickly. Consequently, the biggest challenge today is to extract clinically useful data from overwhelmingly large datasets, and this challenge has become a major research objective in the field of bioinformatics. A key example is that these techniques made it possible to achieve the long-held goal of molecular classification of hepatocellular carcinoma (HCC) [1, 2](fig. 1).

In 2011, the National Cancer Center of Japan achieved a world first by the whole-genome sequencing of HCC using next-generation sequencers [3], and this was successively followed by reports of whole-genome and exome sequencing of HCC by both Japanese and overseas research groups [4-8]. However, in contrast to the well-known high-frequency mutations of epidermal growth factor receptor genes and the anaplastic-lymphoma-kinase fusion gene in lung adenocarcinoma, the whole-genome sequence of HCC revealed the presence of lowfrequency mutations in various genes but no single driver mutation, thereby practically ruling out the possibility that HCC is caused by a single driver mutation. However, since such vast amounts of bioinformatic data are now readily available to clinicians, we believe that if the correct approaches are taken, it is only a matter of time before a paradigm-shattering concept buried deep in bioinformatic data will be found that will revolutionize medical care.

In the field of bioinformatics, a very wide range of applications is possible; for example, it can be used to predict tumor malignancy, optimal treatments, and prognosis. Also, GWAS data are useful for predicting drug sensitivity and adverse effects. This is truly the dawn of the era of individualized medicine, and the application of bioinformatics in the field of oncology is already forging a path to this goal. 


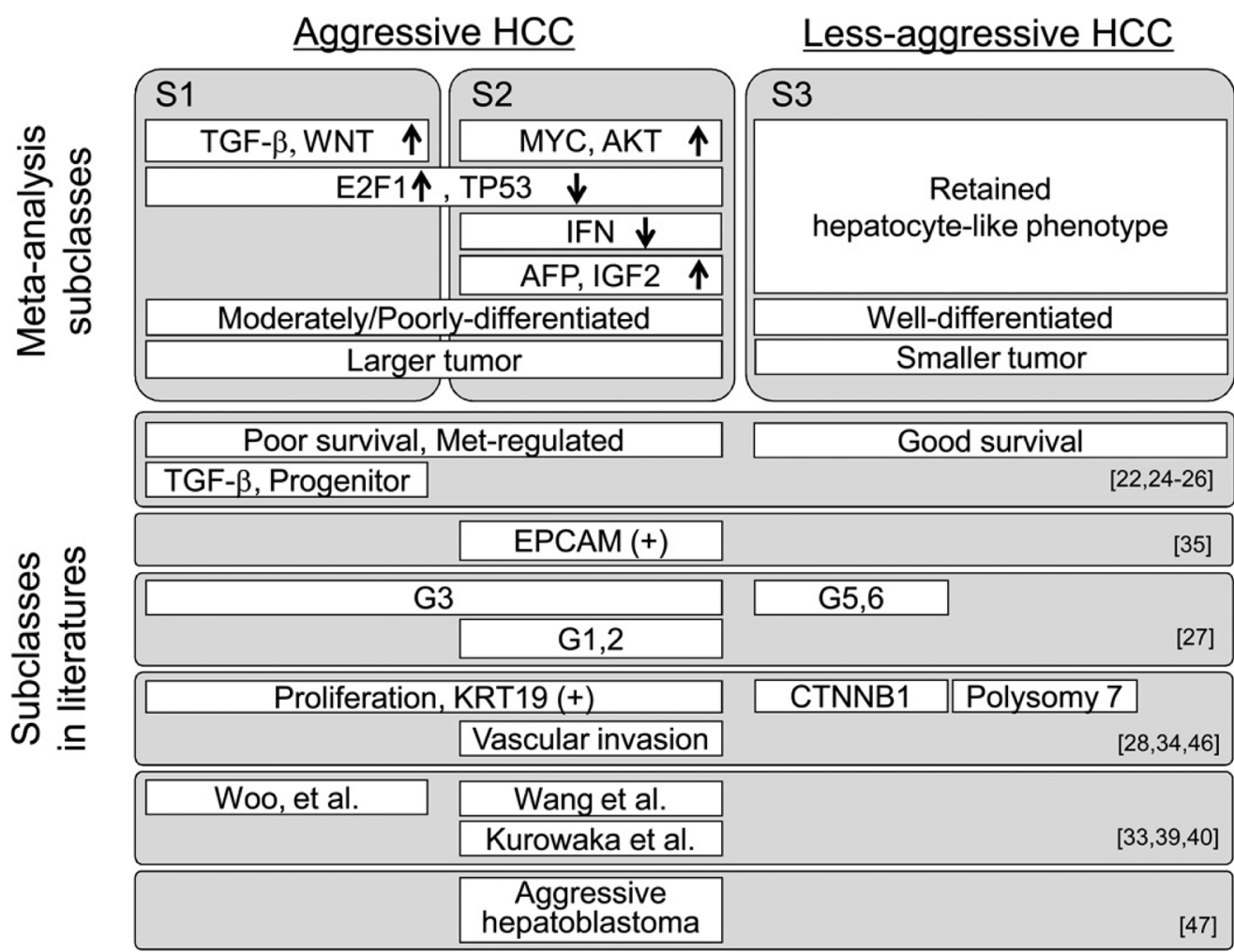

Fig.1. Molecular Classification of Hepatocellular Carcinoma. Reproduced with permission from Hoshida et al.[2].

Work on cancer stem cells continues to attract great attention [9]. It has been reported that approximately $40-50 \%$ of HCC cases exhibit stem cell-like features. Similar to colorectal cancer, a small population of so-called well-differentiated liver cancers may even possess stem cell-like characteristics. On the other hand, several studies have shown that prognosis is poor for HCC expressing Sal-like protein 4 (SALL4) [10-12], a transcription factor and stem-cell marker. Interestingly, knock-down of this single gene transforms the gene expression pattern of HCC cell lines from a stem cell-like pattern to a mature parenchymal cell-like pattern [11]. Some groups have started to report the clinical efficacy of DNA methylation and histone deacetylation inhibitors in SALL4-positive HCC [13]. Is it possible, then, to treat a large population of HCC cells by rewriting genetic information in the epigenome even if no single driver mutation is found? Since the study of SALL4 has just begun, we look forward to future developments in this area.

The field of bioinformatics is still at an early stage of development, and more studies are needed to establish its importance and significance; nonetheless, it clearly has the potential to revolutionize medical care.

\section{References}

1 Hoshida Y, Nijman SM, Kobayashi M, Chan JA, Brunet JP, Chiang DY, Villanueva A, Newell P, Ikeda K, Hashimoto M, Watanabe G, Gabriel S, Friedman SL, Kumada H, Llovet JM, Golub TR: Integrative transcriptome analysis reveals common molecular subclasses of human hepatocellular carcinoma. Cancer Res 2009;69:7385-7392. 
2 Hoshida Y, Toffanin S, Lachenmayer A, Villanueva A, Minguez B, Llovet JM: Molecular classification and novel targets in hepatocellular carcinoma: recent advancements. Semin Liver Dis 2010;30:35-51.

-3 Totoki Y, Tatsuno K, Yamamoto S, Arai Y, Hosoda F, Ishikawa S, Tsutsumi S, Sonoda K, Totsuka H, Shirakihara T, Sakamoto H, Wang L, Ojima H, Shimada K, Kosuge T, Okusaka T, Kato K, Kusuda J, Yoshida T, Aburatani $\mathrm{H}$, Shibata T: High-resolution characterization of a hepatocellular carcinoma genome. Nat Genet 2011;43:464-469.

4 Huang J, Deng Q, Wang Q, Li KY, Dai JH, Li N, Zhu ZD, Zhou B, Liu XY, Liu RF, Fei QL, Chen H, Cai B, Zhou B, Xiao HS, Qin LX, Han ZG: Exome sequencing of hepatitis B virus-associated hepatocellular carcinoma. Nat Genet 2012;44:1117-1121.

5 Sung WK, Zheng H, Li S, Chen R, Liu X, Li Y, Lee NP, Lee WH, Ariyaratne PN, Tennakoon C, Mulawadi FH, Wong KF, Liu AM, Poon RT, Fan ST, Chan KL, Gong Z, Hu Y, Lin Z, Wang G, Zhang Q, Barber TD, Chou WC, Aggarwal A, Hao K, Zhou W, Zhang C, Hardwick J, Buser C, Xu J, Kan Z, Dai H, Mao M, Reinhard C, Wang J, Luk JM: Genome-wide survey of recurrent HBV integration in hepatocellular carcinoma. Nat Genet 2012;44:765-769.

-6 Guichard C, Amaddeo G, Imbeaud S, Ladeiro Y, Pelletier L, Maad IB, Calderaro J, Bioulac-Sage P, Letexier M, Degos F, Clément B, Balabaud C, Chevet E, Laurent A, Couchy G, Letouzé E, Calvo F, Zucman-Rossi J: Integrated analysis of somatic mutations and focal copy-number changes identifies key genes and pathways in hepatocellular carcinoma. Nat Genet 2012;44:694-698.

7 Li M, Zhao H, Zhang X, Wood LD, Anders RA, Choti MA, Pawlik TM, Daniel HD, Kannangai R, Offerhaus GJ, Velculescu VE, Wang L, Zhou S, Vogelstein B, Hruban RH, Papadopoulos N, Cai J, Torbenson MS, Kinzler KW: Inactivating mutations of the chromatin remodeling gene ARID2 in hepatocellular carcinoma. Nat Genet 2011;43:828-829.

8 Fujimoto A, Totoki Y, Abe T, Boroevich KA, Hosoda F, Nguyen HH, Aoki M, Hosono N, Kubo M, Miya F, Arai Y, Takahashi H, Shirakihara T, Nagasaki M, Shibuya T, Nakano K, Watanabe-Makino K, Tanaka H, Nakamura H, Kusuda J, Ojima H, Shimada K, Okusaka T, Ueno M, Shigekawa Y, Kawakami Y, Arihiro K, Ohdan H, Gotoh K, Ishikawa O, Ariizumi S, Yamamoto M, Yamada T, Chayama K, Kosuge T, Yamaue H, Kamatani N, Miyano S, Nakagama H, Nakamura Y, Tsunoda T, Shibata T, Nakagawa H: Whole-genome sequencing of liver cancers identifies etiological influences on mutation patterns and recurrent mutations in chromatin regulators. Nat Genet 2012;44:760-764.

-9 Yamashita T, Ji J, Budhu A, Forgues M, Yang W, Wang HY, Jia H, Ye Q, Qin LX, Wauthier E, Reid LM, Minato H, Honda M, Kaneko S, Tang ZY, Wang XW: EpCAM-positive hepatocellular carcinoma cells are tumor-initiating cells with stem/progenitor cell features. Gastroenterology 2009;136:1012-1024.

10 Oikawa T, Kamiya A, Kakinuma S, Zeniya M, Nishinakamura R, Tajiri H, Nakauchi H: Sall4 regulates cell fate decision in fetal hepatic stem/progenitor cells. Gastroenterology 2009;136:1000-1011.

11 Oikawa T, Kamiya A, Zeniya M, Chikada H, Hyuck AD, Yamazaki Y, Wauthier E, Tajiri H, Miller LD, Wang XW, Reid LM, Nakauchi H: Sal-like protein 4 (SALL4), a stem cell biomarker in liver cancers. Hepatology 2013;57:1469-1483.

12 Yong KJ, Gao C, Lim JS, Yan B, Yang H, Dimitrov T, Kawasaki A, Ong CW, Wong KF, Lee S, Ravikumar S, Srivastava S, Tian X, Poon RT, Fan ST, Luk JM, Dan YY, Salto-Tellez M, Chai L, Tenen DG: Oncofetal gene SALL4 in aggressive hepatocellular carcinoma. N Engl J Med 2013;368:2266-2276.

13 Zeng SS, Yamashita T, Kondo M, Nio K, Hayashi T, Hara Y, Nomura Y, Yoshida M, Hayashi T, Oishi N, Ikeda H, Honda M, Kaneko S: The transcription factor SALL4 regulates stemness of EpCAM-positive hepatocellular carcinoma. J Hepatol 2014;60:127-134. 